\title{
Robert Jewett
}

University of Heidelberg

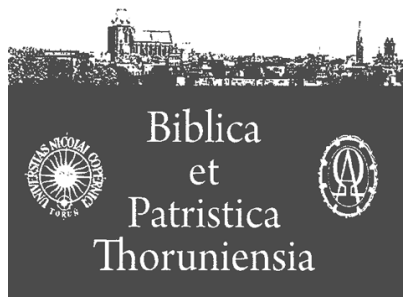

3 (2010)

\section{Interpreting Romans 8:18-23 within the Imperial Context}

In the immense literature on Romans, I have found only one hint that it might relate to Greco-Roman ideas about the corruption and redemption of nature. For example, in his influential studies of Romans in the context of imperial propaganda, Neal Elliott points to thematic parallels between chapters 8 and 13 and observes that the references to suffering "would have evoked sharp echoes" of imperial violence ${ }^{1}$, but rather than dealing with the issue of creation itself, he follows the traditional track in concluding that Paul "requires subordination rather than defiant opposition to the authorities"2. Although Jacob Taubes interpreted Paul's "political theology" as "eine politische Kampfansage an den Cäesaren", he made no effort to address the issue of creation ${ }^{3}$. Bruno Blumenfeld's recent discussion of this passage in The Political Paul makes no reference to Roman attitudes toward nature 4 . Dieter Georgi states that Rom 8 differs from Roman views of the "idyllic" quality of nature, but does not discuss the matter

1 Neil Elliott, "Romans 13:1-7 in the Context of Imperial Propaganda", in R.A. Horsley, ed., Paul and Empire: Religion and Power in Roman Imperial Society (Harrisburg: Trinity Press International, 1997) 194; the word "creation" does not appear in the index of Elliott's study, Liberating Paul: The Justice of God and the Politics of the Apostle (Maryknoll: Orbis, 1994), but on p. 173 there is a reference to Paul's yearning for the "redemption of the whole creation (Rom. 8:22-23)" that evokes Paul's "personal agony for his people, the Jews"; however, Roman imperial views of creation are not in view.

2 Elliott, "Romans 13:1-7", 196.

3 Jacob Taubes, Die Politische Theologie des Paulus. Vorträge gehalten an der Forschungsstätte der evangelischen Studiengemeinschaft in Heidelberg, 23-27 Februar 1987, edited by A. Assmann et al, (Munich: Wilhelm Fink Verlag, 1995) 27.

4 Bruno Blumenfeld, The Political Paul: Justice, Democracy and Kingship in a Hellenistic Framework, JSNTSup 210 (Sheffield: Sheffield Academic Press, 2001) 360-64. 
in detail ${ }^{5}$. He cites the Carmen saeculare that Horace wrote in connection with the imperial games organized by Augustus, but concentrates on the glorification of the emperor rather than on the restoration of nature 6 . I would like to follow Georgi's lead to bring imperial views into more direct correlation with Paul's argument. This lecture is therefore a kind of experiment and I look forward to your critique and suggestions in the discussion that follows. We begin with the imperial side of the dialectic.

\section{The Corruption and Redemption of Nature in Greco-Roman Culture}

In the classical study of Primitivism, there is an account of Hesiod's influential view of nature, in which an original, golden age was depicted as a time of happiness when "the earth produced spontaneously", when there was no violence and the human race lived with luxurious happiness". In Works and Days 109-201 a theory of decline from this idyllic beginning is sketched, in which human failure is linked with nature's corruption. The later ages of silver, bronze and iron are marked by increasing levels of violence and impiety, when humans lose their superior mental and moral qualities. In Aratus' Phaenomena 100-35 and Ovid's Metamorphose 1.89-112 there are similar descriptions of the ages of Gold, Silver and Bronze.

In 44 B.C.E. the young Augustus used the appearance of a comet and the prophecy of Vulcanius concerning the end of one age and the beginning of another to justify the apotheosis of the assassinated Julius Caesar ${ }^{8}$. Virgil provided a "messianic" development in this line of thought. In the Fourth Eclogue 11-41

5 Dieter Georgi, “God Turned Upside Down”, in R.A. Horsley, ed., Paul and Empire: Religion and Power in Roman Imperial Society (Harrisburg: Trinity Press International, 1997) 155.

6 Georgi, “True Prophet”, 36-46.

7 Arthur O. Lovejoy et al, Primitivism and Related Ideas in Antiquity (Baltimore: Johns Hopkins, 1935; repr. New York: Octagon, 1965) 28. See also Lutz Käppel, "Hesiod", RGG ${ }^{4}$ 3 (2000) 1703-04; A. Kurress, "Aetas, Aurea", RAC 1 (1950) 144-50; K. Kubusch, Aurea Saecula. Mythos und Geschichte: Untersuchung eines Motives in der antiken Literature bis Ovid (1986).

8 See John T. Ramsey and A. Lewis Licht, The Comet of 44 B.C. and Caesar's Funeral Games, American Philological Association American Classical Studies 39 (Atlanta: Scholars Press, 1997) 140-45. They note (145) that when Augustus later wrote his Memoires, Vulcanius's prophecy about the end of the ninth age and the beginning of the tenth was "made to concern the return of a Golden Age".

9 Hildebrecht Hommel, "Vergils 'messianisches' Gedicht", in vol. 1 of H. Hommel, Sebasmata. Studien zur antiken relilgionsgeschicte und zum frühen Christentum, (Tübingen: 
a regent is prophesied who would restore the golden age of paradise ${ }^{10}$. In the light of later developmentgs ${ }^{11}$, this prophecy was thought to have been fulfilled when he established the Pax Romana:

And in your counselship... shall this glorious age begin... under your sway, any lingering traces of our guilt shall become void, and release the earth from its continual dread... But for you, child, shall the earth untilled pour forth... Uncalled, the goats shall bring home their udders swollen with milk, and the herds shall fear not huge lions... The serpent, too, shall perish, and the false poison-plant shall perish; Assyrian spice shall spring up on every soil... the earth shall not feel the harrow, nor the vine the pruning-hook; the sturdy ploughman, too, shall now loose his oxen from the yoke.

In the Aeneid VI, 789-94, the link with the reigning Augustus becomes explicit: “... here is Caesar and all of Iulus' progeny, coming beneath the revolving heaven. This man..., Augustus Caesar, son of a god... will establish once more... the Golden Age in the fields once ruled by Saturn".

In Religions of Rome, Beard, North and Rice show that the Saecular Games organized by Augustus in 17 BCE "marked the birth of a new age" in which the "fertility of Mother Earth" was seen to be restored ${ }^{12}$. Paul Zanker describes how Augustus used the appearance of another comet to justify this celebration that announced the beginning of the new age ${ }^{13}$. Horace was commissioned to write the official poem for the celebration, the carmen saeculare, which featured the renewal of nature:

May the earth be fertilell for harvests and herds and give to Ceres her garland of wheat ears;

may the crops be nourished

by Jupiter's good breezes and showers.

Mohr (Siebeck), 1983) 267-72 shows that the poem was written in 41 BC during the period of uncertainty and revolution.

10 Andreas Alföldi, "Der neue Weltherrscher der vierten Ekloge Vergils", Hermes 65 (1930) 369-85, esp. 369 analyzed the propaganda of the divine ruler who will emerge to redeem Rome from its decline and restore paradisaical conditions of plenty on the earth.

11 Hommel, "Vergils 'messianisches' Gedicht", 303 notes that the predicted redemtive king in the poem was the son of the consul Asenius Pollio, Virgil's patron. Apparently it was only later that this prediction was applied to Augustus.

12 Mary Beard, John North and Simon Rice, Religions of Rome (Cambridge: Cambridge University Press, 1998) 1.203; 205, n.126; see also Georgi, "True Prophet", 37.

13 Paul Zanker, The Power of Images in the Age of Augustus (Ann Arbor: University of Michigan Press, 1988, 1990) Chapter 5, p 171 in German edition. See also John T. Ramsey and A. Lewis Licht, The Comet of 44 B. C. and Caesar's Funeral Games, American Philological Association American Classical Studies 39 (Atlanta: Scholars Press, 1997) 140-45. 
A later stanza of Horace's poem celebrates the fusion of morality, peace, and prosperity:

Now Faith and Peace and Honor and ancestral Decency

and slighted Virtue venture to return

and blessed Plenty appears once more

with her brimming horn ${ }^{14}$.

Zanker describes how in the subsequent years one monument after the next was erected to celebrate this restoration of the "fruitfulness of nature"15, that reached its high point in the Ara Pacis Augustae. Daniel Castriota describes the imagery on the Altar of the Augustan Peace as symbolizing "the return of this lost age of bounty and goodness" ${ }^{16}$. Allusions to the promised regeneration of the earth are visible in every aspect of this magnificent altar. The motifs of the ivy and grapevine that appeared in the fourth Eclogue as signs of the new age are prominently displayed on the altar ${ }^{17}$. New plants are invented to depict the paradisal conditions of a world made truly new, as Zanker observes, while the organization of plants and animals in rows and ranks conveys the new, hierarchical order ${ }^{18}$. These scenes are coordinated with scenes of victory over the Parthians, which serve to confirm the divine blessing on the new regime ${ }^{19}$. The twin pillars on the altar symbolize piety and conquest, both of which were allegedly blessed by the gods. The political implication was reinforced by the placement of the Altar on the Campus Martius in relation to the gigantic Solarium Augusti in such a way that the pointer of the sundial would shine directly onto the altar on September 23, Augustus' birthday ${ }^{20}$.

The central figure on the peace altar is Mother Earth restored, a female figure representing Rome sitting at ease with "two children and pomegranates, grapes and nuts on her lap; in front of her a cow and a sheep... The central figure clearly represents notions of fertility (human and agricultural), set between images of sky and sea... ${ }^{21}$ Castriota concludes "For the Romans of the Augustan period, the conception of the Golden Age embodied on the Ara Pacis was essentially one of renewal--the renewal of time and the renewal of bounteous life".

14 Zanker, cited on pp. 174-77, 180 from the German edition.

15 Zanker, 177 from the German edition.

16 David Castriota, The Ara Pacis Augustus and the Imagery of Abundance in Later Greek and Early Roman Imperial Art (Princeton: Princeton University Press, 1995) 125.

17 Castriota, Ara Pacis Augustus, 135.

18 Zanker, Power of Images, 184-86.

19 Zanker, Power of Images, 189.

20 Castriota, Ara Pacis Augustus, 131.

21 Beard et al, Roman Religion, 204; discussing Figure 4.6. 
The Ara Pacis was widely emulated as depictions of a fruitful Mother Earth came to center stage on coins and altars in the period of Augustus and his successors $^{22}$. For instance, a grand public altar in Carthage has the figure of Earth with a "globe and cornucopia in front of her", which Beard, et al, believes was adapted from a Roman design ${ }^{23}$. While these motifs were present on Roman coins in the decades prior to Augustus, he combined them with the theme of pieta,the proper honoring of the gods that would ensure the Golden Age with his victory ${ }^{24}$. One of his coins has the ruler with divine light streaming from his head while he stands with his foot on the globe and holds the symbols of the "return of the Golden Age", including the cornucopia ${ }^{25}$.

This propaganda continued with four subsequent emperors in poetry, art and the civic cult. For example, Lovejoy cites Calpurnius Siculus, Eclogue, that was composed in Neronian times to relate these themes to the ruling emperor:

Rejoice, first of all, dwellers in the forests, rejoice, $\mathbf{O}$ my people. Though all your flocks wander without a guardian, and the shepherd neglect to close them in at night..., yet no thief shall lay his traps near the sheep-fold nor loosen the tethers of the beasts of burden to drive them off. The golden age of untroubled peace is born again, and kindly Themis returns to earth freed from stain and rust. The happy times are ruled by a youth [i.e. Nero] who won the victory while still in his mother's arms. When he shall himself reign as a god... Peace will appear... and clemency has broken in pieces the weapons of madness... Full peace will come upon us, a peace which... shall bring back a second reign of Saturn ${ }^{26}$.

Since the "madness" of non-Roman warfare and the corruption of barbaric impiety had ruined the world, in Calpurnius' view, Nero's reign brings peace that is blessed by the gods. His magical "victory" allegedly restores nature to its original state in the primeval Age of Saturn, when beasts of the field were so tame that they herded themselves, and when the earth brought forth its harvest without the use of the plow. This imperial vision of the former corruption and current redemption of Mother Earth differs from Romans 8 at virtually every point and provides a suitable foil for reassessing the relevance of its argument.

22 See Ilona Opelt, “Erde”, RAC 5 (1962) 1136-38.

23 Beard et al, Roman Religion, 333.

24 Alföldi, "neue Weltherrscher", 376.

25 On p. 385 of "neue Weltherrscher", Alföldi provides a number of other Roman coins containing the cornucopia motif. See also Johannes B. Bauer, "Horn I", RAC 16 (1994) 544-46.

26 Calpurnius Siculus, Eclogue I, 33-99. 


\section{A Reading of Romans 8:18-23 within the Imperial Context}

I view Romans is an epideictic letter that does not indulge in polemics. We should therefore anticipate that the relation of this passage to the prevailing Roman view of nature is implicit. In thinking through the implications of Paul's formulation against the foil of the imperial context, we also need to take account of the impact of the previous argument in the letter. Whereas the Roman cult touted piety and conquest as the means whereby the Golden Age was restored, Paul's letter rejects salvation by works in all its forms. Whereas the Roman premise was that disorderly barbarians and rebels caused the corruption of nature, Paul argues that all humans reenact Adam's fall. In place of imperial victory celebrations and administration as the hinge of the Golden Age, Paul touts the power of the gospel to convert the world. Moreover, as the wording of 8:18-23 indicates, the natural world is far from idyllic and its restoration has certainly not been accomplished by the Roman government. I translate the relevant verses on the handout:

Rom 8:18 For I reckon that the sufferings of the present time are not equivalent with the coming glory to be revealed to us.

19 For the eager expectation of the creation awaits the revelation of the sons of God.

20 For the creation was subjected to futility, not voluntarily but on account of the one who subjected it in hope

21 because the creation itself will also be freed from the slavery to corruption and obtain the liberation consisting of the glory for the children of God.

22 For we know that the whole creation groans together and travails together until now,

23 and not only [the creation] but even ourselves who have the first fruits of the spirit,

even we ourselves, groan within ourselves

as we await the redemption of our body.

While noting that the sufferings experienced by the saints was a traditional motif ${ }^{27}$, commentators tend to overlook the contextual implications that this

27 See for instance Heinrich Schlier's discussion based on 4 Ezra 13:16-19; Syrian Baruch 25:1-3; 2 Thess 1:4 in Römerbrief, HThKNT 6 (Freiburg: Herder, 1977) 257. James D.G. Dunn, Romans 1-8 WBC 38a (Dallas: Word, 1988) 468-69 cites Dan 7:21-22, 25-27; 12:1-3; Jubilee 23:22-31; Testament of Moses 5-10; 1QH 3:28-36; Sibylline Oracles 3:632-56 and Matt 3:7-12 and parallels in support of the contention that "Paul is taking over an earlier eschatological schema" in this verse. Walther Bindemann's claim in Die Hoffnung der Schöpfung. Römer 8,18-27 und die Frage einer Theologie der Befreiung von Mensch und Natur, Neukirchener Studienbücher 14 (Neukirchen: Neukirchener, 1983) 82-95 that Paul is 
formulation would have carried for the Roman believers. Paul's formulation simply assumes, without arguing the point, that the Caesarean view about the presence of a peaceful, magically prosperous Golden Age is illusory. The term $\pi \alpha \theta \eta \dot{\eta} \mu \alpha \tau \alpha$ ("passions, sufferings") appears in 8:18 with the article, indicating that the topic is known to the audience. The plural form is typical of Pauline usage (2 Cor 1:5, 6, 7; Gal 5:24; Phil 3:10; Col 1:24), referring to the sufferings that believers should expect in following a suffering Christ ${ }^{28}$. This wording continues the theme of suffering together with Christ in 8:17.

The expression $\tau \dot{\eta} \nu \mu \epsilon^{\prime} \lambda \lambda \lambda_{0} \sigma \alpha \nu$ ó $\xi \alpha \nu$ should be translated in the adjectival sense of "the future glory". I find it particularly significant that Paul uses the expression "to be revealed" in a manner parallel to the thesis of Romans ${ }^{29}$, conveying an apocalyptic disclosure of the triumph of God. Despite the illusions of the Roman civic cult, the originally intended glory of the creation shall yet be restored, including specifically the glory humans were intended to bear. The

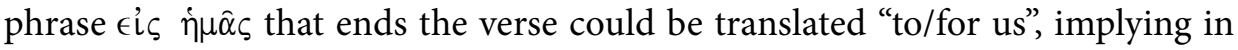
John Murray's view that the glory is "to be bestowed upon [believers/us], so that [they/we] become the actual partakers; it is not a glory of which we are to be mere spectators" ${ }^{30}$. In contrast to imperial claims, this is not a glory that shines from the head of Caesar alone.

The concept of "glory" implied in this passage is in fact quite distant from the classical Greco-Roman sense of opinion, reputation, or renown ascribed by public opinion; it is closely related to the Hebrew sense of בבוד / ס ס ס weightiness, honor, beauty, fiery presence, splendor, or power ${ }^{31}$. Human beings were created to reflect such glory (Psalm 8:1,5), which is particularly visible in the wise (Prov 11:16; 20:3), and symbolized throughout the ancient Near East by the royal crown or diadem ${ }^{32}$. When persons or nations become corrupt, they lose their glory (Hos 4:7; 9:11; Jer 2:11; Ez 24:25), but when Yahweh redeems them, their glory is restored (Isaiah 35:1-2). The connection in Rom 8:18 between "revelation" and the restoration of "glory" is derived from a major stream of prophetic and post-exilic expectations. Isaiah 24:23 forsees the time "when the Lord will reign on Mount Zion and in Jerusalem, and before his elders he will

polemicizing here against an apocalyptic scheme stressing the distance of God seems overly abstract and unrelated to the cultural context.

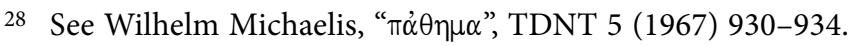

29 See Dunn 470.

30 John Murray, The Epistle to the Romans: The English Text with Introduction, Exposition, and Notes, NICCNT (Grand Rapids: Eerdmans, 1997) 301.

31 See Gerhard Kittel, “סó $\xi \alpha$, TDNT 2 (1964) 233-51, esp. 247. See also Weinfeld, “בוד", TWAT 4 (1982) 38.

32 Weinfeld, “בבור", 30-31. 
reveal his glory". Deutero-Isaiah forsaw a universal extension of this idea in 40:5, "then the glory of Yahweh shall be revealed, and all flesh shall see it together"

In the light of this background and of Paul's argument concerning the present experience of faith in the midst of suffering, it seems appropriate to say that Paul intends the beleagered Christ-believers in Rome to discern in the growing triumph of the gospel the initial evidence of this glory that will one day fill the creation (cf. 2 Cor 3:18).

In verse 19 Paul explains the cosmic scope of divine glory by introducing the

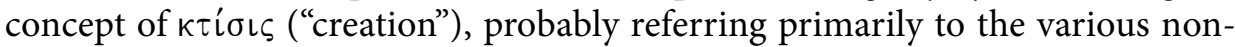
human components of the universe ${ }^{34}$. In contrast to Greco-Roman views of the eternal, Mother Earth, $\kappa \tau i$ i $\iota \varsigma$ implies purposeful creation of the natural order by God at a particular moment in time. The biblical creation stories are in view here, but in contrast to Genesis, there is a striking measure of personification in Paul's view of the non-human world; it is capable of $\dot{\alpha} \pi о к \alpha \rho \delta о \kappa i \alpha$ ("eager expectation"), just as humans are (Phil 1:20). This word, attested only in these two passages written by Paul, conveys a positive connotation of "confident expectation" 35 , very much in contrast to the relaxed depictions of Mother Earth in the Ara Pacis. The attitude is contrasting, but the personification is similar. This personification of creation is also parallel to what Ollie Christofferson has detected in an apocalyptic treatment of the flood tradition (1 Enoch 7:6) where the earth takes on human qualities as it lays accusation against its abusers ${ }^{36}$. Paul implies that the entire creation waits with baited breath for the emergence and empowerment of those who will take responsibility for its restoration, small

33 See Weinfeld, "כבוד", 37.

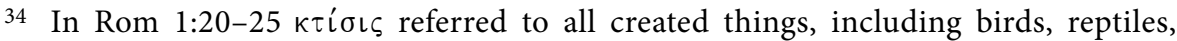
and humans. But Ulrich Wilckens, Der Brief an die Römer, EKKNT 6 (Zürich: Benziger; Neukirchen-Vluyn: Neukirchener Verlag, 1978-82) 2.152-53 and C.E.B. Cranfield, A Critical and Exegetical Commentary on the Epistle to the Romans. ICC (Edinburgh: Clark, 1975) 411-12 advance compelling arguments that neither non-Christian believers nor the angelic forces are implied in the formulation of 8:19. See also B.R. Brinkman, "'Creation' and 'Creature' II. Texts and Tendencies in the Epistle to the Romans", Bijdr 18 (1957) 359-74 and John G. Gibbs, Creation and Redemption: A Study in Pauline Theology, NovTSup 26 (Leiden: Brill, 1971).

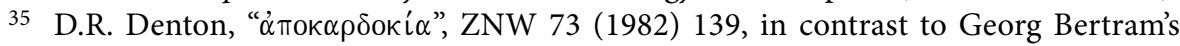
problematic argument from etymology that the term carries a sense of anxious waiting, in

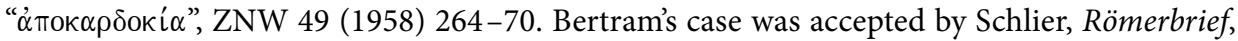
259 and Ulrich Wilckens, Römer, 152. As noted by Gustav Adolf Deissmann, Light from the Ancient East, trans. L.R.M. Strachan (Grand Rapids: Baker, 1965) 374, note 5, a verbal form of the word that lacks any sense of anxiety appears in Polybius, Hist. 18.31, "to expect earnestly $(\dot{\alpha} \pi о \kappa \alpha \rho \delta о \kappa \in \hat{\imath} \nu)$ the arrival of Antiochus".

36 Olle Christoffersson, The Earnest Expectation of the Creature: The Flood-Tradition as Matrix of Romans 8:18-27 (Stockholm: Almqvist \& Wiksell, 1990) 120. 


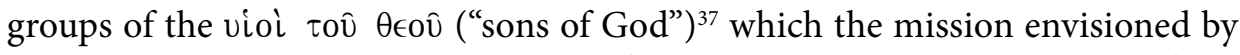
Romans hopes to expand to the end of the known world, i.e. to Spain. These converts take the place of Caesar in the imperial propaganda about the Golden Age, but they employ no weapons to vanquish foes. When Paul speaks of their "revelation/unveiling", there is a clear reference to God's glory advancing in the world, in this instance, through the triumph of the gospel. Persuasion rather than conquest is the means of this transformation.

In Rom 8:20, the explanation of creation's yearning for redemption is provided by allusion to the Genesis story, where the perversion of the originally good and glorious garden commenced. In this myth, it is the progenitor of the entire human race who was responsible for the corruption of the Garden, not the enemies of Roman imperialism. The use of the divine passive, i $\operatorname{\epsilon } \epsilon \dot{\alpha} \gamma \eta$ ("was subjected"), points to God's action in response to Adam's fall ${ }^{38}$. In the Genesis account, the divine curse upon the ground resulted in its producing "thorns and thistles", causing chronic frustration symbolized by the "sweat" on the face of Adam's descendents (Gen 3:17-19). In this powerful symbolization, humans trying to play God ended up ruining not only their relations with each other but also their relation to the natural world (cf. also Hos. 4:1-3). The Roman myth system claimed the exact opposite: that a ruler who plays god can restore the world to a paradisal condition by his piety and military dominance.

Paul's choice of the term $\mu \alpha \tau \alpha$ เó $\tau$ ' ("emptiness, vanity, futility") to depict this situation would have led hearers to think of the somber dictum of Ecclesiastes, which portrays this same dilemma:

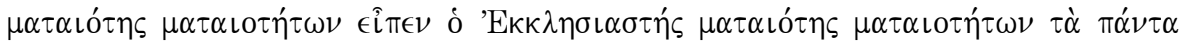

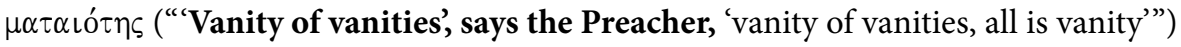
(Eccl 1:2).

This dilemma is more basic than the resultant "corruption" to be mentioned in Rom 8:2139. Given the use of $\mu \alpha \tau \alpha$ เó $\omega$ ("make vain, empty") in Rom 1:21 to

37 Fitzmyer 507 states the widely shared consensus: "'the revelation of the sons of God' refers to glorified Christians.... Christofferson's suggestion in Earnest Expectation, 120-24 that the "sons of God" are the angelic powers widely discussed in apocalyptic literature does not comport well with the references to the "sonship" of believers in Rom 8:15 and 23 . However, his study helps to highlight the fact that Paul places believers in the role of the redemptive angels of 1 Enoch and elsewhere, or in the immediate context of the Roman civic cult, in the role of Caesar.

38 See the discussion in Wilckens, Römer, 154; Murray 303 refers to this verse as "Paul's commentary on Gen. 3:17,18". Dunn 470 observes that there is "now general agreement" on this point.

39 See Schlier's critique in 260-61 of the exegetical consensus of most ancient and modern commentators who argue for the essential identity of "vanity" and "corruption". 
describe the frustration and destructiveness of persons or groups who suppress the truth and refuse to recognize God, it seems likely that Paul has in mind the abuse of the natural world by Adam and all of his descendents. The basic idea is that the human refusal to accept limitations ruins the world. By acting out idolatrous desires to have unlimited dominion over the garden, the original purpose of the creation--to express divine goodness (Gen 1:31) and reflect divine glory (Psalm 19:1-4)--was emptied ${ }^{40}$. As in Ecclesiastes 2:1-17, it is the drive for fame, prestige, and immortal achievement that evacuates the goodness and glory of the creation and piles up endless frustrations in the human interaction with the natural environment, symbolized in Genesis by the "thorns and thistles" (Gen 3:18). That such vanity in the form of the Pax Romana had promised the restoration of the age of Saturn appears utterly preposterous in the light of this formulation.

The somewhat awkward qualification in verse 20 that the futility of the non-

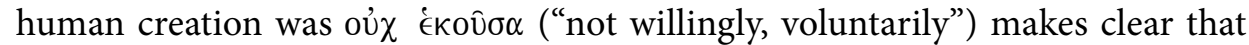
Paul does not subscribe to a gnostic view of the world as innately frustrating and evil. The fall of nature was "not through its own fault" ${ }^{41}$ because it is the human race that remains responsible for the defacing of the ecological system. Here Paul continues the personified manner of speaking about nature, as if it would have preferred not to participate in the sinful futility caused by Adam and Eve and

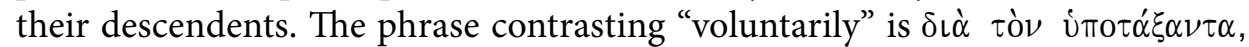

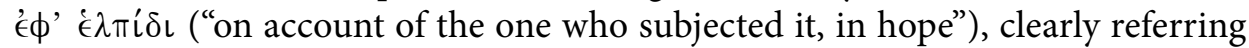
to God's curse against the land in response to human $\sin ^{42}$. We find the same idea derived from Genesis in 4 Ezra 7:1, "And when Adam transgressed my statutes, what had been made was judged". The "hope" in this passage, to be elaborated in 8:21, is that the human race, which had defaced the world, would be redeemed and begin to participate in removing the curse from the land ${ }^{43}$.

He mentions Ambrosiaster, Theodoret, Augustinus, Thomas Aquinas, Estius, Bisping, H.W. Schmidt, Althaus, Lietzmann, and Michel; to this list one could add Chrysostom, Jülicher, Lipsius, Zahn, Kühl and others; see Otto Kuss, Der Römerbrief übersetzt und erklärt (Regensburg: Pustet, 1957-78) 626.

40 Cranfield 413 refers to the creation "not being able properly to fulfill the purpose of its existence". Schlier's explanation in 260 is so subtly existential, with the creation absolutizing itself just as humans do, that the causitive link between human sin and ecological futility is rendered obscure.

41 Cranfield 414.

42 It is implausible to suggest that either Adam or Satan may be identified as the "one subjecting it in hope", because neither can be understood as acting "in hope". See Kuss $627-28$.

43 See Franz-J. Leenhardt, The Epistle of Saint Paul to the Romans: A Commentary, trans. H. Knight (London: Lutterworth, 1961) 125-26. 
Paul's wording makes it absolutely clear that such redemption is not a present political achievement as the Roman civic cult was maintaining.

In verse 21 Paul elaborates this hope, that the creation "shall itself also be freed" 44 from the Adamic distortion. This takes up a significant theme in Jewish prophetism and apocalypticism ${ }^{45}$, which articulate in a contrasting manner some of the themes in the Roman expectation. Isaiah's vision of a messianic future includes both a king who will restore righteousness among humans (Isa 11:4-5) and a restoration of Edenic conditions between animals and humans (Isa 11:6-9; $65: 17,25 ; 66: 22)$. Jubilees envisions the time when "the heavens and the earth shall be renewed" (Jub 1:29). 1 Enoch speaks of regaining access to the "fragrant tree" on the seventh mountain which restores the joy and long life of Eden (1 Enoch 24-25; see also 91:16-17), while the Testament of Levi anticipates a messianic priest who "shall open the gates of paradise, and shall remove the threatening sword against Adam. And he shall give to the saints to eat from the tree of life, and the spirit of holiness shall be on them" (Test. Levi 18:10-11). 4th Ezra expects the messianic "Man from the Sea" to "deliver his creation" from the perils of violence (4 Ezra 13:26). The Sibylline Oracles predicts a time after the day of judgment and the arrival of a just empire when the earth will once again become "the universal mother who will give to mortals her best fruit in countless store of corn, wine and oil... And the cities shall be full of good things and the fields rich" (Sib. Or. 3, 744-45; 50-51). The Oracles reiterate Isaiah's vision of wolves and lambs eating grass together, with no creature harming others (Sib. Or. 3. 788-95).

As we have seen, Paul's version of this Edenic hope features the converted "children of God" (Rom 8:19). Although the future tense of the verb Paul selects, 'ं $\lambda \in \cup \theta \in \rho \omega \theta \eta \dot{ } \sigma \in \tau \alpha \iota$ ("it will be freed") in 8:21, clearly correlates with the "revelation of the sons of God" in verse $19^{46}$, the inference is rarely drawn concerning the means by which God intends to restore the natural world. Heinrich Schlier is exceptional in referring to the "responsibility that Christians have not only for themselves but also for the realm of pure creatureliness" ${ }^{47}$. Overcoming ecological disorder is depicted here as a divine gift enacted as a result of God's restoration

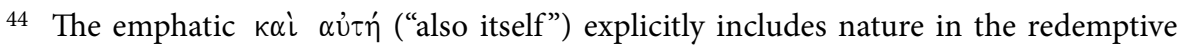
process, rendering implausible C.K. Barrett's comment in A Commentary on the Epistle to the Romans, HNTC (New York: Harper, 1991, 2nd ed.) 165 that Paul "is not concerned with creation for its own sake".

45 Gowan's survey in "Fall and Redemption", 100-102, concludes that apocalyptic literature echoes but does not extensively develop the Biblical theme.

46 Cranfield 415.

47 Heinrich Schlier, Der Römerbrief, HThKNT 6 (Freiburg: Herder, 1977) 262-63 restricts this responsibility to the arena of a proper existential attitude toward nature, refraining from any discussion of ethical responsibility. 
of humanity to its position of rightful dominion, reflecting God's intended glory. In the place of a Caesar with a sunburst about his head, the glory proclaimed by Paul will be shared by every converted person, whether slave or free, male or female, Roman or barbarian ${ }^{48}$.

In 8:22-23 Paul moves on to place human suffering within the context of the creation's groaning for redemption. The expression $\pi \hat{\alpha} \sigma \alpha \dot{\eta} \kappa \tau i ́ \sigma \iota \varsigma$ ("the whole creation") includes the entire range of animate and inanimate objects on earth and in the heavens. The personification of creation noted earlier is continued in this verse by the birth metaphors of groaning and travailing. These metaphors resonate with Greco-Roman images of "Mother Earth". Once again, the personification stands parallel to Roman usage, but in place of nature's joy at its deliverance through Augustus and his successors, Paul hears only agonized groans.

Paul moves beyond traditional usage in two ways, by imagining nature as a whole undergoing such birth pangs, and by the anaphoric reduplication of

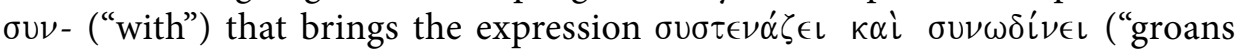
together and travails together") into a rhetorically unified expression. In Paul's formulation the "together" refers to the shared experience of believers and the creation as a whole, both yearning for the future restoration. There is an unparalleled coherence in this expression that combines the suffering of creation from the time of Adam with a metaphor of hope--travail, the agony that leads to a new birth ${ }^{49}$. Paul views the creation as a holistic, interdependent system with a life and development of its own, yet anticipating appropriate human intervention to counter Adam's fall. The emphatic reference to the "whole" creation and the unique use of the compound verbs with ouv - suggests that human beings along with the rest of creation are included in this groaning; perhaps it would be better to say these clues provide rhetorical hints at human

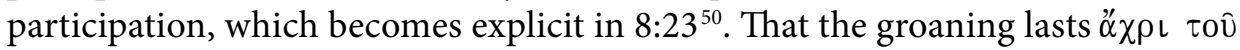
vôv ("until now") echoes the eschatological emphasis of $8: 18^{51}$ while including

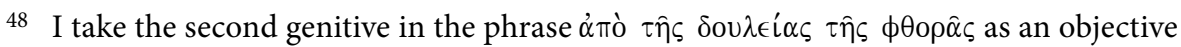
genitive, "from the bondage to corruption", following Lipsius who refers to corruption as "a ruling power". For an argument in favor of a genitive of quality, see Günther Harder,

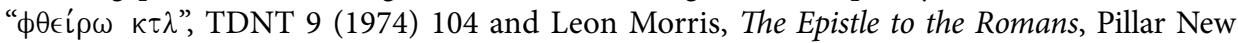
Testament Commentary (Grand Rapids: Eerdmans, 1988) 322.

49 Schlier 264, referring to Paul Claudel's discussion in Conversations dans le Loir-etCher (Paris: Gallimand, 1935) 255.

50 See F.R. Montgomery Hitchcock, “'Every Creature', Not 'All Creation' in Romans viii. 22", ExpT 8 (1916) 372-83.

51 Barrett 166 and Dunn 473, move beyond a verbal echo to contend that this expression conveys a unique eschatological emphasis. 
the suffering presently experienced and witnessed in the natural world within the painful legacy of the fall ${ }^{52}$. If the groaning really lasts "until now", this would exclude the Augustan premise that the New Age had been inaugurated in 17 B.C.E., or that Nero had ushered in a "Golden Age of untroubled peace".

That believers are included in the suffering of creation is developed in verse 23 , which serves to eliminate any exceptionalism for those who have the supreme gift of the spirit. I take the participle " $\chi 0 \nu \tau \epsilon \varsigma$ in the simple attributive sense of believers "having" the first fruits of the spirit. Paul's point is that no matter how charismatically they may be endowed, believers continue to participate in the suffering to which the entire world has been subjected as a result of sin. By associating the spirit with human vulnerability, Paul effectively eliminates any project of apotheosis such as he had confronted in Corinth. This is highly relevant for the Roman context, whose civic cult centered on the apotheosis of Caesar.

It is rather puzzling at first glance that Paul would refer to 'awaiting sonship' as a future fulfillment in 8:23 when he had spoken so clearly in 8:15 of the spirit confirming the sonship of believers as a present experience. The clue is in his

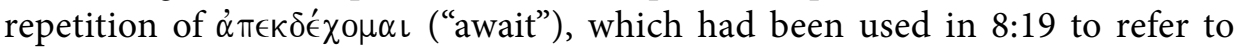
awaiting the "revelation of the sons of God" ${ }^{3}$. The content of the future hope is that the full and undistorted dominion of God's children will one day manifest itself in the context of a restored creation. In the Roman context, this futurity has decisive significance. Thus the phrase Paul selects to explain this restoration

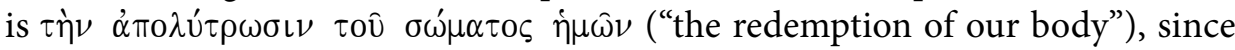
body is the basis of communicating and interacting with the world ${ }^{54}$. Paul hopes for a socially transformed corporeality within the context of a transformed creation that is no longer subject to "corruption" 55 .

52 See Cranfield 417; Wilckens 2. 156.

53 This is an instance where the literal language of "sonship" needs to be preserved despite its chauvinistic implications, because if the less offensive term "adoption" is used in 8:15 and 23 as in the NRSV and Dunn 452, 474, the link with "the revelation of the sons of God" in 8:19 is obscured. The translation "adoption" is in any case a secondary choice, since adoption places a person in the category of sonship. For a discussion of the use of vio $\theta \in \sigma i \alpha$ in the sense of legal adoption, see G.H.R. Horsley, " $\kappa \alpha \theta$ ' vio $\theta \epsilon \sigma i \alpha \nu$ ", NDIEC 4 (1987) 173; the reflections of Greek legal practice render implausible Francis Lyall's contention in "Roman Law in the Writings of Paul-Adoption", JBL 88 (1969) 458-66 that Paul's usage reflects only Roman practice. In "Petition to a Prefect", NDIEC 3 (1982) 16-17, Horsley discusses an alternate term for adoption not used by Paul, $\tau \in \kappa \nu o ́ \theta \in \sigma \iota \varsigma$, indicating the adoption of a girl.

54 See Jewett, Paul's Anthropological Terms: A Study of Their Use in Conflict Settings, AGAJU 10 (Leiden: Brill, 1971) 218-19; 254-79.

55 See J.A. Ziesler, Paul's Letter to the Romans, TPINTC (London: SCM; Philadelphia: Trinity Press International, 1989) 222. 
The "new creation" of 2 Cor 5:17 and Gal 6:15 is clearly in view here. Although the tension between the 'already' and the 'not yet' will not be overcome until the parousia, Paul's purpose is to encourage the Roman church members to begin enacting their sonship right now, in refusing to conform to the fallen age, and resolutely acting rightly toward the groaning creation, of which their bodies are a part. The arena for such action was narrower for the members of Roman house and tenement churches than for later Christian communities, probably consisting mainly of the spheres of bodily responsibility in work, family, and congregational life; and given the purpose of Romans, the sphere of mission. By participating in the Spanish Mission, Paul is offering the Romans a concrete opportunity to enact their rightful sonship and contribute to the ultimate restoration of the creation. Given the presumption of powerlessness on the part of the underclass represented by most of the Roman house and tenement churches in a dictatorial society, such prospects would have appeared grandiose and unrealistic--without the premise of eschatological hope. However, compared with believing that the Roman gods had already ushered in the Golden Age through a victorious Caesar, Paul's hope could lead to a more realistic forms of collective responsibility for the creation.

\section{Interpretacja Rzymian 8, 18-23 w kontekście imperialnym}

\section{Streszczenie}

Autor zwraca uwagę na pomijany, acz ważki jego zdaniem temat w literaturze dotyczącej interpretacji listu do Rzymian, a mianowicie na kwestię zepsucia i odkupienia natury. Twierdzi on, że fragment Rz 8,18-23 staje się o wiele bardziej zrozumiały w świetle grecko-rzymskich poglądów na naturę. Według współczesnej Pawłowi propagandy imperialnej, barbarzyńcy i buntownicy spowodowali zepsucie natury. Stąd rzymski kult oraz podboje były środkami przywracania jej właściwego wymiaru. Dzięki temu w świecie natury na powrót mogła zapanować harmonia (Złota Epoka). Natomiast Paweł zdecydowanie odrzuca pogląd, jakoby zbawienie zależało od jakichkolwiek uczynków. Według niego jedynie potęga ewangelii jest w stanie przywrócić harmonię w naturze.

\section{Summary}

The author deals with an important but often neglected topic in the literature concerning the interpretation of the Letter to the Romans - namely, the matter of corruption and redemption of the human nature. He believes the fragment Rm 8:18-23 becomes far more comprehensible in light of Greco-roman views on the nature. Paul argues with those commonly accepted pagan assumptions in this matter and states firmly that only the power of the Gospel is capable of bringing harmony to the nature. 